\title{
MEMBANGUN BUDAYA ANTI-NARKOTIKA MELALUI PENINGKATAN PEMAHAMAN MENGENAI REGULASI DI BIDANG NARKOTIKA
}

\author{
Imelda Martinelli ${ }^{1}$, Ade Adhari ${ }^{2}$, Luisa Srihandayani ${ }^{3}$ dan Malvin Jati Kuncara Alam ${ }^{4}$
}

\author{
${ }^{1}$ Fakultas Hukum, Universitas Tarumanagara, Jakarta \\ Email: imeldam@fh.untar.ac.id \\ ${ }^{2}$ Fakultas Hukum, Universitas Tarumanagara, Jakarta \\ Email: adea@fh.untar.ac.id \\ ${ }^{3}$ Program Studi Magister Hukum, Universitas Diponegoro, Semarang \\ Email: luisas.15.07@gmail.com \\ ${ }^{4}$ Fakultas Hukum, Universitas Tarumanagara, Jakarta
}

\begin{abstract}
The country of Indonesia is facing a "Narcotics Emergency". This is because the level of narcotics abuse in Indonesia is very high. Narcotics abuse is one of the threats to the progress of the civilization of the Indonesian nation. In order to overcome this problem, it is necessary to increase understanding of the dangers of narcotics and various regulations on narcotics control in Indonesia. This is the goal of implementing PKM at SMAN 17. Jakarta. The stages of PKM implementation consist of identifying problem, drafting proposals, managing PKM implementation permits, implementing PKM, compiling PKM outputs, compiling PKM progress reports and preparing PKM final reports. Partners also participate in PKM activities, namely by conveying information about the implementation of PKM at SMAN 17 Jakarta to XI students of SMA 17, coordinating with class leaders in each class XI SMA 17 to participate in PKM activities and arranging attendance required at the time of implementation of PKM at SMAN 17 Jakarta. The results of the PKM implementation show an increase in understanding of the anti-narcotics culture as conveyed by students after the implementation of PKM activities. The conclusion that can be put forward is that SMAN 17 students gain an understanding of the various laws and regulations used by the state to tackle narcotics. In addition, it is necessary to strive for PKM activities that carry this theme in various other schools.
\end{abstract}

Keywords: Anti-Narcotics Culture, Narcotics Abuse

\begin{abstract}
ABSTRAK
Negara Indonesia tengah menghadapi kondisi "Darurat Narkotika". Hal tersebut dikarenakan tingkat penyalahgunaan narkotika di Indonesia sangat tinggi. Penyalahgunaan narkotika adalah salah satu ancaman bagi kemajuan peradaban bangsa Indonesia. Dalam rangka mengatasi masalah ini perlu dilakukan peningkatan pemahaman mengenai bahaya narkotika dan berbagai regulasi penanggulangan narkotika di Indonesia. Inilah yang menjadi tujuan pelaksanaan pengabdian kepada masyarakat (PKM) di SMA 17 Jakarta ini. Tahapan pelaksanaan PKM terdiri dari tahap penggalian informasi permasalahan, penyusunan proposal, pengurusan izin pelaksanaan PKM, pelaksanaan PKM, penyusunan luaran PKM, penyusunan laporan kemajuan PKM dan penyusunan laporan akhir PKM. Mitra juga ikut berpartisipasi dalam kegiatan PKM, yaitu dengan menyampaikan informasi tentang adanya pelaksanaan PKM di SMAN 17 Jakarta kepada siswa XI SMA 17, mengadakan koordinasi dengan ketua kelas di masing-masing kelas XI SMA 17 untuk mengikuti kegiatan PKM dan menyusun absensi yang dibutuhkan pada saat pelaksanaan PKM di SMAN 17 Jakarta. Hasil pelaksanaan PKM menunjukan adanya peningkatan pemahaman mengenai budaya anti-narkotika sebagaimana disampaikan oleh para siswa pada saat setelah dilaksanakannya kegiatan PKM. Kesimpulan yang dapat dikemukakan adalah bahwa siswa SMAN 17 mendapatkan pemahaman mengenai berbagai peraturan perundang-undangan yang digunakan oleh negara untuk menanggulangi narkotika. Selain itu, perlu diupayakan kegiatan PKM yang mengangkat tema seperti ini di berbagai sekolah lainnya.
\end{abstract}

Kata Kunci: Budaya Anti-Narkotika, Penyalahgunaaan Narkotika

\section{PENDAHULUAN}

Masalah narkoba telah menjadi masalah yang banyak mendapat perhatian yang cukup serius oleh masyarakat. Kasus narkoba di negeri ini dari tahun ke tahun mengalami peningkatan, bahkan Indonesia dianggap memiliki prospek yang bagus untuk pasar peredaran narkoba global. Mengutip kata-kata Humas Badan Narkotika Nasioal (BNN) Sumirat yang mengatakan bahwa Indonesia sebagai good market and good price, artinya Indonesia dianggap sebagai pasar yang bagus dan juga memiliki prospek bisnis yang bagus untuk peredaran barang terlarang itu (Putranto \& Suyatmi, 2015). 


\section{Gambar 1}

Jumlah Kejadian Kejahatan Narkotika, Tahun 2014-2018 (Badan Pusat Statistik, 2019)

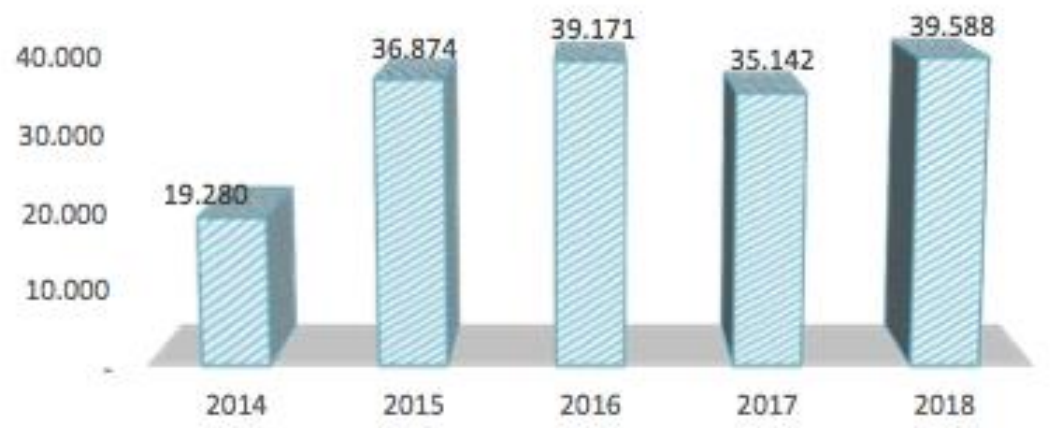

\section{Gambar 2}

Jumlah Kejadian Kejahatan Narkotika menurut Polda, Tahun 2018 (Badan Pusat Statistik, 2019)

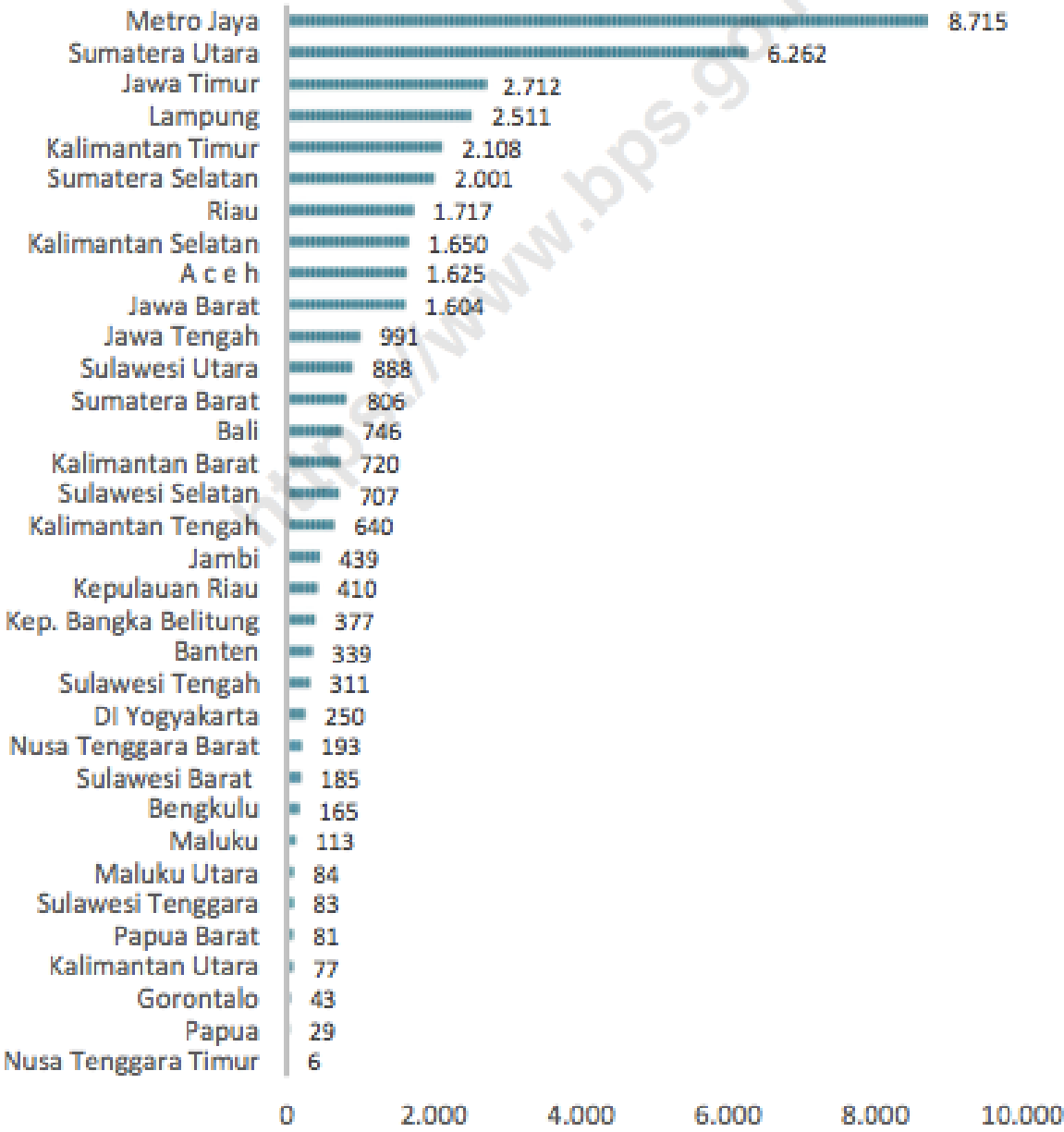


Penyalahgunaan narkotika adalah salah satu ancaman bagi kemajuan peradaban bangsa Indonesia (Fanaqi \& Pratiwi, 2019). Persoalan Penyalahgunaan Narkoba menjadi permasalahan yang tidak bisa dipandang sebelah mata. Tingkat penyalahgunaan ini semakin hari semakin menunjukkan kenaikan yang cukup signifikan (Eleanora, 2011). Dalam Statistik Kriminal 2019 sebagaimana dirilis oleh Badan Pusat Statistik (BPS), dinyatakan bahwa Jenis kejahatan yang termasuk kejahatan luar biasa (extraordinary crime) ini memiliki pola yang berbeda dengan kejahatan lain. Berdasarkan Gambar 2.16, jumlah kejadian kejahatan terkait narkotika (drugs) di Indonesia pada 2014 - 2018 cenderung meningkat. BPS menampilkan jumlah kejadian kejahatan terkait narkotika dari Tahun 2014-2018 dalam grafik pada Gambar 1.

Dalam Statistik Kriminal 2019 tersebut juga ditampilkan data jumlah kejadian kejahatan terkait narkotika menurut polda, pada tahun 2018. Jumlah kejadian kejahatan tersebut dapat dilihat pada Gambar 2.

Maraknya tingkat penebaran narkotika di Indonesia, salah satunya disebabkan karena posisi Indonesia. Indonesia berdekatan dengan wilayah the Golden Triangle atau segitiga emas negara pusat produksi, penyelundupan dan perdagangan narkotika terbesar di AsiaTenggara. The Golden Triangle beranggotakan Thailand, Myanmar dan Laos. Negara di kawasan Asia Tenggara termasuk Indonesia merupakan negara tujuan The Golden Triangle. Kondisi ini tentunya dapat berpengaruh besar terhadap perdagangan ilegal dan korban penyalahgunaan narkotika di Indonesia (Antiprawiro, 2014). Soedjono mengungkapkan Narkoba mempunyai dampak negatif yang sangat luas baik secara fisik, psikis, ekonomi, sosial, budaya, hankam, dan lain sebagainya. Bila penyalahgunaan narkoba tidak diantisipasi dengan baik, maka akan rusak bangsa dan negara ini. Oleh karena itu, diperlukan kerja sama yang baik dari seluruh komponen bangsa untuk penanggulangan penyalahgunaan narkoba (Eskasasnanda, 2014). Dalam rangka merespon bahaya narkotika, negara telah menetapkan berbagai peraturan perundang-undangan, diantaranya Undang-Undang Nomor 35 Tahun 2009 tentang Narkotika (UU Narkotika).

Berdasarkan informasi yang disampaikan oleh SMAN 17 Jakarta selaku mitra pelaksana PKM kali ini didapatkan pemahaman bahwa:

1. Siswa belum memahami maksud atau tujuan utama pemberantasan penyalahgunaan narkotika;

2. Siswa belum memahami secara substansial berbagai regulasi yang mengatur tentang pemberantasan penyalahgunaan narkotika;

3. Siswa belum memahami secara menyeluruh bagaimana kebijakan pencegahan dan penanggulangan penyalahgunaan narkotika; dan

4. Siswa belum memahami perannya dalam mendukung program pemerintah dalam mencegah dan menanggulangi penyalahgunaan narkotika

Berbagai ketentuan normatif dalam UU Narkotika perlu disosialisasikan ke para siswa SMAN. 17 Jakarta agar meningkatkan kesadaran hukum terhadap kebijakan larangan penyalahgunaan narkotika yang ditetapkan oleh negara, yang pada akhirnya menumbuhkan budaya anti-narkotika. Beranjak pada uraian tersebutlah perlu diadakan pengabdian kepada masyarakat di SMAN. 17 Jakarta dengan mengangkat tema "Membangun Budaya Anti-Narkotika melalui Peningkatan Pemahaman Regulasi di Bidang Narkotika".

\section{METODE PELAKSANAAN PKM}

Pelaksanaan pengabdian kepada masyarakat di SMAN 17 Jakarta diselenggarakan melalui berbagai tahapan yakni: 
1. Tahapan Penggalian Informasi Permasalahan

2. Tahapan Penyusunan Proposal

3. Tahapan Pengurusan Izin Pelaksanaan PKM

4. Tahapan Pelaksanaan PKM

5. Tahapan Penyusunan Luaran PKM

6. Tahapan Penyusunan Laporan Kemajuan PKM

7. Tahapan Penyusunan Laporan Akhir PKM

Dalam kegiatan pelaksanaan pengabdian kepada masyarakat di SMAN 17 Jakarta, partisipasi mitra dalam berbagai bentuk yakni:

1. menyampaikan informasi tentang adanya pelaksanaan pengabdian kepada masyarakat di SMAN 17 Jakarta kepada siswa ke XI SMA 17;

2. mengadakan koordinasi dengan ketua kelas di masing-masing kelas XI SMA 17 untuk mengikuti kegiatan pengabdian kepada masyarakat; dan

3. menyusun absensi yang dibutuhkan pada saat elaksanaan pengabdian kepada masyarakat di SMAN 17 Jakarta.

\section{HASIL DAN PEMBAHASAN}

Budaya anti-penyalahgunaan narkotika merupakan solusi yang dapat digagas dalam rangka menanggulangi penyalahgunaan narkotika yang semakin massif. Hal ini dikarenakan pencegahan dan penanggulangan penyalagunaan narkotika tidak akan berhasil apabila hanya menitikberatkan adanya UU Narkotika dan aparat penegak hukum, lebih dari pada itu budaya hukum yakni budaya anti-penyalahgunaan narkotika memegang peranan penting. Sebagaimana diketahui bahwa hukum adalah bangunan sistem yang dapat operasional dengan baik apabila seluruh komponennya diperhatikan dengan baik. Komponen tersebut tentunya bukan hanya adanya UU Narkotika (Substansi Hukum), Aparat Penegak Hukum (Struktur Hukum) dan Budaya Anti-Penyalahgunaan Narkotika (Budaya Hukum).

Padal Pasal 1 angka 1 UU Narkotika, narkotika didefinisikan sebagai zat atau obat yang berasal dari tanaman atau bukan tanaman, baik sintetis maupun semisintetis, yang dapat menyebabkan penurunan atau perubahan kesadaran, hilangnya rasa, mengurangi sampai menghilangkan rasa nyeri, dan dapat menimbulkan ketergantungan, yang dibedakan ke dalam golongan- golongan sebagaimana terlampir dalam Undang-Undang ini. UU Narkotika mengatur banyak hal antara lain:

1. golongan narkotika;

2. pencegahan dan pemberantasan penyalahgunaan narkotika;

3. penyidikan, penuntutan dan pemeriksaan perkara penyalahgunaan narkotika di sidang pengadilan,; dan

4. ketentuan pidana terhadap pelaku penyalahgunaan narkotika.

Terhadap penyalahgunaan narkotika terdapat kebijakan hukum pidana yang digunakan untuk menanggulangi. Kebijakan tersebut tertuang dalam Bab XV tentang Ketentuan Pidana. terdapat berbagai perbuatan yang oleh UU Narkotika dinyatakan sebagai tindak pidana antara lain:

a. tanpa hak atau melawan hukum menanam, memelihara, memiliki, menyimpan, menguasai, atau menyediakan Narkotika Golongan I dalam bentuk tanaman;

b. menanam, memelihara, memiliki, menyimpan, menguasai, atau menyediakan Narkotika Golongan I dalam bentuk tanaman sebagaimana dimaksud pada ayat (1) beratnya melebihi 1 (satu) kilogram atau melebihi 5 (lima) batang pohon;

c. tanpa hak atau melawan hukum memiliki, menyimpan, menguasai, atau menyediakan Narkotika Golongan I bukan tanaman; 
d. memiliki, menyimpan, menguasai, atau menyediakan Narkotika Golongan I bukan tanaman sebagaimana dimaksud pada ayat (1) beratnya melebihi 5 (lima) gram;

e. tanpa hak atau melawan hukum memproduksi, mengimpor, mengekspor, atau menyalurkan Narkotika Golongan I;

f. memproduksi, mengimpor, mengekspor, atau menyalurkan Narkotika Golongan I sebagaimana dimaksud pada ayat (1) dalam bentuk tanaman beratnya melebihi 1 (satu) kilogram atau melebihi 5 (lima) batang pohon atau dalam bentuk bukan tanaman beratnya melebihi 5 (lima) gram;

g. tanpa hak atau melawan hukum menawarkan untuk dijual, menjual, membeli, menerima, menjadi perantara dalam jual beli, menukar, atau menyerahkan Narkotika Golongan I;

h. menawarkan untuk dijual, menjual, membeli, menjadi perantara dalam jual beli, menukar, menyerahkan, atau menerima Narkotika Golongan I sebagaimana dimaksud pada ayat (1) yang dalam bentuk tanaman beratnya melebihi 1 (satu) kilogram atau melebihi 5 (lima) batang pohon atau dalam bentuk bukan tanaman beratnya 5 (lima) gram;

i. tanpa hak atau melawan hukum membawa, mengirim, mengangkut, atau mentransito Narkotika Golongan I;

j. membawa, mengirim, mengangkut, atau mentransito Narkotika Golongan I sebagaimana dimaksud pada ayat (1) dalam bentuk tanaman beratnya melebihi 1 (satu) kilogram atau melebihi 5 (lima) batang pohon beratnya melebihi 5 (lima) gram;

k. tanpa hak atau melawan hukum menggunakan Narkotika Golongan I terhadap orang lain atau memberikan Narkotika Golongan I untuk digunakan orang lain;

1. Dalam hal penggunaan narkotika terhadap orang lain atau pemberian Narkotika Golongan I untuk digunakan orang lain sebagaimana dimaksud pada ayat (1) mengakibatkan orang lain mati atau cacat permanen;

m. tanpa hak atau melawan hukum memiliki, menyimpan, menguasai, atau menyediakan Narkotika Golongan II;

n. Dalam hal perbuatan memiliki, menyimpan, menguasai, menyediakan Narkotika Golongan II sebagaimana dimaksud pada ayat (1) beratnya melebihi 5 (lima) gram;

o. tanpa hak atau melawan hukum memproduksi, mengimpor, mengekspor, atau menyalurkan Narkotika Golongan II;

p. Dalam hal perbuatan memproduksi, mengimpor, mengekspor, atau menyalurkan Narkotika Golongan II sebagaimana dimaksud pada ayat (1) beratnya melebihi 5 (lima) gram;

q. tanpa hak atau melawan hukum menawarkan untuk dijual, menjual, membeli, menerima, menjadi perantara dalam jual beli, menukar, atau menyerahkan Narkotika Golongan II;

r. Dalam hal perbuatan menawarkan untuk dijual, menjual, membeli, menerima, menjadi perantara dalam jual beli, menukar, atau menyerahkan Narkotika Golongan II sebagaimana dimaksud pada ayat (1) beratnya melebihi 5 (lima) gram;

s. tanpa hak atau melawan hukum membawa, mengirim, mengangkut, atau mentransito Narkotika Golongan II;

t. Dalam hal perbuatan membawa, mengirim, mengangkut, atau mentransito Narkotika Golongan II sebagaimana dimaksud pada ayat (1) beratnya melebihi 5 (lima) gram;

u. tanpa hak atau melawan hukum menggunakan Narkotika Golongan II terhadap orang lain atau memberikan Narkotika Golongan II untuk digunakan orang lain;

v. Dalam hal penggunaan Narkotika terhadap orang lain atau pemberian Narkotika Golongan II untuk digunakan orang lain sebagaimana dimaksud pada ayat (1) mengakibatkan orang lain mati atau cacat permanen;

w. tanpa hak atau melawan hukum memiliki, menyimpan, menguasai, atau menyediakan Narkotika Golongan II; 
x. Dalam hal perbuatan memiliki, menyimpan, menguasai, menyediakan Narkotika Golongan III sebagaimana dimaksud pada ayat (1) beratnya melebihi 5 (lima) gram;

y. tanpa hak atau melawan hukum memproduksi, mengimpor, mengekspor, atau menyalurkan Narkotika Golongan III;

z. Dalam hal perbuatan memproduksi, mengimpor, mengekspor, atau menyalurkan Narkotika Golongan III sebagaimana dimaksud pada ayat (1) beratnya melebihi 5 (lima) gram;

aa. tanpa hak atau melawan hukum menawarkan untuk dijual, menjual, membeli, menerima, menjadi perantara dalam jual beli, menukar, atau menyerahkan Narkotika Golongan III;

bb. Dalam hal perbuatan menawarkan untuk dijual, menjual, membeli, menerima, menjadi perantara dalam jual beli, menukar, atau menyerahkan Narkotika Golongan III sebagaimana dimaksud pada ayat (1) beratnya melebihi 5 (lima) gram;

cc. tanpa hak atau melawan hukum membawa, mengirim, mengangkut, atau mentransito Narkotika Golongan III;

dd. Dalam hal perbuatan membawa, mengirim, mengangkut, atau mentransito Narkotika Golongan III sebagaimana dimaksud pada ayat (1) beratnya melebihi 5 (lima) gram;

ee. tanpa hak atau melawan hukum menggunakan Narkotika Golongan III terhadap orang lain atau memberikan Narkotika Golongan III untuk digunakan orang lain;

ff. Dalam hal penggunaan Narkotika terhadap orang lain atau pemberian Narkotika Golongan III untuk digunakan orang lain sebagaimana dimaksud pada ayat (1) mengakibatkan orang lain mati atau cacat permanen;

gg. Orang tua atau wali dari pecandu yang belum cukup umur, sebagaimana dimaksud dalam Pasal 55 ayat (1) yang sengaja tidak melapor;

hh. tanpa hak atau melawan hukum: a. memiliki, menyimpan, menguasai, atau menyediakan Prekursor Narkotika untuk pembuatan Narkotika; b. memproduksi, mengimpor, mengekspor, atau menyalurkan Prekursor Narkotika untuk pembuatan Narkotika; c. menawarkan untuk dijual, menjual, membeli, menerima, menjadi perantara dalam jual beli, menukar, atau menyerahkan Prekursor Narkotika untuk pembuatan Narkotika; d. membawa, mengirim, mengangkut, atau mentransito Prekursor Narkotika untuk pembuatan Narkotika

\section{KESIMPULAN DAN SARAN}

Dalam kesempatan ini simpulan yang dapat dikemukakan bahwa Siswa SMAN 17 yang dalam hal ini merupakan mitra dari pelaksanaan PKM mendapatkan pemahaman mengenai berbagai peraturan perundang-undangan yang digunakan oleh negara untuk menanggulangi narkotika. Hal tersebut diperlukan untuk meningkatkan pemahaman sehingga dapat menjadi fondasi dalam membangun budaya anti-narkotika. Selain itu, diharapkan kegiatan semacam ini dapat dilakukan di SMA lainnya.

Ucapan Terima Kasih (Acknowledgement)

Terima kasih kepada LPPM Untar atas pembiayaan pelaksanaan PKM dan kepada SMAN 17 Jakarta yang sudah berkenan menjadi mitra.

\section{REFERENSI}

Putranto, A. D. \& Suyatmi. (2015). Kontrol sosial tim pencegahan, pemberantasan, penyalahgunaan dan perderan gelap narkoba (P4GN) dan komunitas terhadap bahaya penyalahgunaan narkoba di Kabupaten Sukoharjo. Jurnal Sosiologi Dilema, 30(1).

Fanaqi, C. \& Pratiwi, R. M. (2019). Partisipasi masyarakat dalam pencegahan narkoba di Garut. Jurnal Komunikasi Hasil Pemikiran dan Penelitian, 15(1). 
Eleanora, F. N. (April 2011). Bahaya penyalahgunaan narkoba serta usaha pencegahan dan penanggulangannya (suatu tinjauan teoritis). Jurnal Hukum, $X X V(1)$.

Antiprawiro, G. (2014). Peran masyarakat dalam pencegahan dan penanggulangan terhadap penyalahgunaan dan peredaran gelap narkotika. Sociale Polites, 15(2).

Eskasasnanda, I. D. P. (Juni 2014). Fenomena kecanduan narkotika. Sejarah dan Budaya, Tahun Kedelapan(1).

Undang-Undang Nomor 35 Tahun 2009 tentang Narkotika 